\title{
HOTS LEARNING MODEL IMPROVES THE QUALITY OF EDUCATION
}

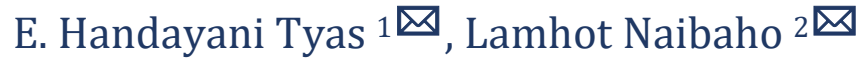 \\ ${ }^{1}$ Magister of Education Management, Postgraduate Program, Universitas Kristen, Indonesia \\ 2 English Study Program, Faculty of Education and Teacher Training, Universitas, Indonesia
}

D0I: https://doi.org/10.29121/granthaalayah.v9.i1.2021.3100

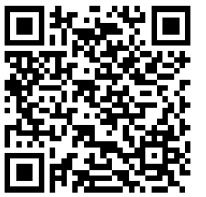

Article Type: Research Article

Article Citation: E. Handayani Tyas, and Lamhot Naibaho. (2021). HOTS LEARNING MODEL IMPROVES THE QUALITY OF EDUCATION.

International Journal of Research GRANTHAALAYAH, 9(1), 176-182. https://doi.org/10.29121/granthaa layah.v9.i1.2021.3100

Received Date: 01 January 2021

Accepted Date: 31 January 2021

Keywords:

Quality of Education

HOTS Learning Model

Industrial Revolution Era 4.0

\section{ABSTRACT}

This paper aims to describe that the HOTS learning model can improve the quality of education. Quality education is an absolute prerequisite for the progress of a country, both at the regional, national, and especially international levels. The fourth industrial revolution has changed the way we live, work and collaborate with others. The technology developed in the fourth industrial revolution combines the physical, digital and biological worlds, which on the one hand opens up great opportunities for progress, but on the other hand, also raises no small potential dangers. To answer such a huge challenge, we as education observers will immediately take steps and use the right strategy, namely by implementing a learning model based on Higher Order Thinking Skills (HOTS). The importance of HOTS in the XXI century and the era of the industrial revolution 4.0 and why HOTS should be because the characteristics of HOTS learning are learning that can develop creativity. Learning to think critically and make decisions, learning to solve problems. This research uses a qualitative approach with a research library design. The findings of this study are that the HOTS learning model is suitable for improving the quality of learning, both in schools and universities, in other words, the HOTS learning model improves the quality of the education.

\section{INTRODUCTION}

The world is changing rapidly when technological tools make the teaching and learning process more manageable; school digitization is inevitable. The industrial revolution 4.0 demands a fast but precise response through the use of technology. The digitalization of education makes us not just surrender to the old proverb "be slow as long as you survive" or "allon-alon-alon from a play" ("slowly from the road") [1], [2], [3]. In an era when the internet of things has penetrated all corners of the earth, accompanied by a large variety of data (big data) and artificial intelligence which continues to develop, the teaching and learning process can no longer be done just manually [4], [5]. Technology development is far from being imagined in the past, as technological tools are increasingly widespread and affordable [6].

This condition provides an opportunity for anyone to have and access much information inclusively. Through a variety of applications based on artificial intelligence, students are helped in learning and developing themselves [7], [8]. However, all that requires guidance. Teachers are still in charge of providing a moral compass and cannot allow students to freefall in the digital universe [9]. Teachers should position themselves as facilitators and motivators in addition to their primary duties as educators. School digitization is undoubtedly an integral part of the education

(C) 2021 The Author(s). This is an open access article distributed under the terms of the Creative Commons Attribution License, which permits unrestricted use, distribution, and reproduction in any medium, provided the original author and source are credited. 
Hots Learning Model Improves the Quality of Education

strategy 4.0 [10]. The goal is to prepare Indonesian children to respond to the challenges of the industrial revolution 4.0 and the future [11]. This program further indicates that the link between education and the digital universe is increasingly inevitable. The approach rests on a balance of access and quality. All citizens of the nation without exception have the right to access quality education [12]. If somebody wants to advance and win the competition in this limitless world, the key is to improve education quality!

In an era when internet networks have penetrated in all fronts, transparent and measurable policies are needed to develop digitalization of education as a sustainable program [13], [14]. For the government, the main thing is to create a collaborative and conducive education culture so that students' creativity can develop optimally because the energy of creativity is a fire that must continue to burn [15], [16]. Creativity is a part of humans' uniqueness that cannot be replaced by machines or any sophisticated artificial intelligence. Creativity is the estuary of human taste, creativity and initiative, which is the essence of a superior human being framed by a strong moral character. Character education strengthening programs have been running in some schools [17], [18]. However, there are still schools that are confused about "grounding" this educational method. Strengthening Character Education runs in 188,000 schools or 86 per cent of total schools in Indonesia. There is confusion in applying the five values of religiosity, integration, nationalism, independence, and cooperation so that there are schools that interpret character education by increasing religious rituals. Different targets!

\section{METHOD}

This method of the study used is a qualitative approach with the "Library Research" design, where researchers as "key instruments" read theories that are directly related to the topic of "High Order Thinking Skill Learning Model and the theory of education quality" sourced from books, journals and proceedings (Pubmed, Google Scholar, Google with keywords building a culture of tolerance since early childhood) as well as other documents and turn them into research data which were analyzed descriptively.

\section{DISCUSSION}

As intended by Article 1 Chapter I Sisdiknas Law No. 20 of 2003, that: "Education is a conscious and planned effort to create an atmosphere of learning and the learning process so that students actively develop their potential to have religious, spiritual strength, self-control, personality, intelligence, noble character, and skills needed by themselves, the community. , nation and state". Departing from Article 1 above, every educational institution should carry out spiritual development, and this can be done inside or outside the classroom, whether packaged in learning or extra-curricular. Because with solid faith and devotion, it is hoped that the graduates will be far from anarchic, corrupt, moral decadence, and others [19]. Meanwhile, the obligation to educate the nation's children to become creative and capable human beings is explicitly stated in Article 3 of the Sisdiknas Law, namely: "National Education has the function of developing capabilities and shaping noble national character and civilization in order to educate the nation's life, aimed at developing the potential of students, so that be a human being who believes and has a devotion to God Almighty, has a noble character, is healthy, knowledgeable, capable, creative, independent, and becomes a democratic and responsible citizen [20]. The fact proves that the learning process that has taken place so far has not entirely shaped students to become competent, independent, and creative. Even though several strategies have been launched, among others, changing the curriculum for each change of ministers followed by changing policies, they still have not been able to achieve the national education goals as expected. The curriculum is a tool to achieve educational goals itself.

"The curriculum is a set of plans and arrangements regarding the objectives, content and learning materials as well as the methods used as guidelines for implementing learning activities to achieve certain educational goals". Education personnel are now required to be problem finders and problem solvers at the same time. That is what is desired to improve and advance education in Indonesia [21]. Therefore, the HOTS-based learning model is one way of preparing students who are ready to compete in the face of the millennium era and the 4.0 industrial revolution, on the other hand, the teacher must be able to direct students to be able to think critically, analytically, build cooperation or collaboration, and able to provide conclusions or problem-solving [22]. Indonesia needs superior humans who have competitiveness and who can answer or provide solutions as it is known as 3C +1 I (Complex Problem Solving, Critical Thinking, Creative + Innovative). 


\section{E. Handayani Tyas, and Lamhot Naibaho}

The educational process that can prepare human resources with thinking skills has become a global need (das solen). However, in reality, some school/university graduates do not have the XXI century's competences, namely creativity, critical thinking, communication, and collaboration [23]. Critical thinking is related to the ability to extract meaning from a given statement or data. A person capable of critical thinking must be able to reason and make interpretations [24]. Meanwhile, creative thinking is related to developing ideas or ideas, for example, new products that did not exist before. Realizing this, various tips to improve the quality of education must be taken. The HOTS model is a suitable learning method to develop or improve higher-order thinking skills. Nowadays, students can access and search for information from the internet quickly. They can immediately find out and get information that teachers usually convey easily and quickly via the internet. It causes the teacher, who previously served as one of the primary sources of information, to be less precise [25]. As a result, teachers who persist by delivering conventional teaching materials will gradually no longer be respected and are not even respected by their students.

Now we are faced with a choice, change or stay in our comfort zone, change or die! The teacher has shifted his role, and he must be competent at placing himself as a reliable learning facilitator [26]. Able to develop students' abilities, filter information critically and be able to develop ideas or ideas creatively, and be able to synergize with students like working "a pair of chopsticks" (two chopsticks). The use of various sources of information and various learning methods should be something that needs to be applied by teachers when in class. Educators (lecturers/teachers) are not all-knowing people, and students are not entirely ignorant people [27]. Educators have certain advantages that must be used to teach students. Educators and students are human beings who are the focus of learning. Individual educators as parties who convey knowledge and learners individually carry out learning activities to form self-concept for themselves. Success in learning requires a set of learning methods to implement it, and for that, of course, a set of relevant skills is also needed, so that the entire series of teaching and learning activities can be understood more effectively and efficiently [28].

Various learning methods include (1) lectures, (2) assignments and recitation, (3) discussion, (4) question and answer, (5) experiments, (6) demonstrations, (7) fieldwork, (8) works to travel, (9) problem solving, (10) case studies, (11) socio drama, (12) projects, (13) exercises (14) brainstorming, (15) role-playing, and there are many more, all of which depend heavily on (a) preparation, (b) formulation of objectives, (c) the ability of teachers/educators, (d) students' learning abilities, (e) group size, (f) time, (g) facilities. Each method certainly has advantages and disadvantages. Therefore educators must be able to process and present them attractively and professionally so that learning can be fun (joyful learning) [29]. Apart from the various methods mentioned above, other methods are no less attractive. Therefore, educators and students are expected to continue to explore and find other methods that will undoubtedly add insight and knowledge about teaching and learning. The following are tips that are expected to help educators support success in carrying out their duties, namely: How do educators direct students' attention and how can they make students active from an early age?

Gagne and Briggs suggested the sequence of learning activities as follows: a) Directing the attention of students; b) Tells the goals to be achieved; c) Stimulate the emergence of memory about the required skills or knowledge that has been learned; d) Delivering learning materials that are used as stimuli; e) Provide instructions or guidance in learning activities; f) Fishing the appearance of students; g) Provide feedback (feedback); h) Assess the performance of learning outcomes, and i) Stimulate the ability to remember (learning outcomes) [30].

Meanwhile, how lecturers/teachers make students active from an early age can be explained as follows: a) When the lecturer/teacher starts the lesson, it is essential (for you) to make students active from an early age. If not, then you will run the risk of capacity building such as "cement is just waiting to dry"; b) Various opening activities (learning) are made so that students get to know more, invite their thoughts, and provoke their attention in the subject; c) These experiences can be considered as 'appetite generators' for food full of appetite stimulants giving learners a hunger that must be overcome and subsequently need to be followed carefully, and d) Even though some lecturers/teachers choose to start a lesson only with a brief observation, but at least adding an introductory exercise to lesson planning, is an essential and beneficial first step [31].

Taking about five minutes for the opening activities (depending on the length of your lesson) will be an excellent time to spend. All of these goals, when achieved, will significantly help develop a learning environment that involves students, develop their willingness to participate in learning (active learning), and create positive classroom norms. It can be concluded that the things that can achieve the success of the learning process are through or by using the methods and methods described above. HOTS-based learning must make all students think actively, so that the role of the lecturer/teacher is not so dominant in the learning process, but instead acts as a facilitator to make it easier for students to think [32]. Students are allowed to develop their thinking skills so that they master higher-order 
Hots Learning Model Improves the Quality of Education

thinking skills. Lecturers/teachers provide more opportunities for students to find and discover what they will learn [33].

Some of the conditions that must be applied during learning activities are as follows: a) Ensuring the situation remains under control even though students are challenged to carry out learning activities freely during the learning process; b) Lecturers/teachers provide more stimulating thinking to students to solve the problems that have been given or the problems at hand. It will cause students to be more active in seeking information and thinking so that the learning material will be more easily absorbed and their thinking skills will improve; c) Carrying out varied learning activities, adjusted to the characteristics and needs of students, because monotonous learning will make students feel bored, especially if only listening to lecturers/teachers talk, and d) Stimulating students to dare to submit their opinions or statements and questions (statement and question). Lecturers/teachers can train students to make statements and questions after presenting an exciting phenomenon, such as videos, demonstrations, or other means. Lecturers/teachers must train their students' self-confidence to believe in themselves in mastering knowledge and thinking [34].

Learning that requires students to formulate problems is HOTS-based learning. Students need to be able to formulate a problem from the given conditions. Learning activities with an inquiry approach, in general, must begin with the formulation of a problem or question that will be sought for a solution through investigation activities [35]. It is often done when trying to solve a problem to make it easier for students to understand the problem. Problemposing and problem-solving can be used to identify individual creativity. Many other experts state that asking questions in the form of questions or problems can train students to think creatively. If the introduced problem does not have straightforward questions, then the student must learn to formulate it. It is an opportunity to practice creativity in solving problems. So, the activity of formulating problems is a creative thinking process. Students' ability to formulate problems and find solutions is a means to assess creativity and encourage students to develop their creativity.

Creativity development requires divergent thinking skills. Training students to think divergent will develop their ability to propose several different ideas or ideas. The development of ideas or creative ideas is closely related to the ability to think divergent. The ability to think convergent is also needed to find out which solution is the most efficient or gives the best results [36]. Besides, learning by seeking information from various sources will accommodate differences in student/student characteristics in learning styles, learning abilities, needs, interests, curiosity, and initial knowledge of each student. They will be freer to learn and construct their knowledge. It is the activity which encourages students to be responsible and practise independent learning. It requires higher-order thinking skills and cannot be accomplished by merely understanding or implementing a procedure.

Given the effectiveness of HOTS-based learning, every lecturer/teacher is encouraged to apply several principles in HOTS-based learning, including: a) Creating assignments that are in accordance with the expectations or needs of students; b) Generating students' curiosity; c) Provide assignments or questions that can make students think actively; c) Assessing real (contextual) problems experienced by students; d) Developing the imagination of students through writing/drawing; e) Provide opportunities students to do elaboration and think divergent (lateral); f) Give students the opportunity to choose a topic or way of learning in class; g) Not blaming students for making or asking strange things; h) Provide freedom of experimentation students; i) Provide feedback and appreciation for students work; j) Train students to ask questions and formulate problem formulations in an effort to solve challenging problems; k) Train students to think critically by analyzing and evaluating the data or information presented; l) Train students to make decisions related to a condition that is described [37].

Creative people generally like to do experiments or try something new. It is because he feels dissatisfied with what he has been doing so far, thus encouraging him to do other things that are considered new and challenging. An attitude of openness to new experiences is one of the characteristics of creative and innovative people. He does not like static things, so he does not want to be silent and tends to ask questions frequently and provide various solutions. Indeed, this trait is recommended by the current Indonesian Minister of Education and Culture. Lecturers/teachers who want to make their students think creatively must implement creative learning strategies to involve students in processes and creative thinking [38]. The use of pure discovery learning approaches and unsupervised learning became less effective and efficient (sangkil and sangkil) to direct students.

Thus, the teacher must apply learning that can lead students to think creatively so that the application of specific learning approaches and strategies must be followed by a mechanism to monitor the creative process. For example, if a lecturer/teacher applies a free inquiry strategy (free inquiry), the lecturer/teacher must become a facilitator in directing students to formulate problems and plan an investigation. Obtaining the skills as expected, 
lecturers/teachers are required to train students to think divergent or lateral thinking, because the development of students' imaginations is significant to foster their creativity. The imagination is more important than knowledge because creativity starts from imagination. "Imagination is more important than knowledge. For a while, knowledge defines all we currently know and understand; imagination points to all we might yet discover and create. It is supported by Osborn who stated that there should be no criticism to train creative thinking. Furthermore, in general, the direct instruction model is not used in HOTS-based learning. However, this learning model can be applied to improve students' ability to think at a higher-order level with some adjustments (adjustments are made using short lectures), which are interspersed with questions or assignments to students to work on worksheets to improve higher-order thinking skills.

\section{CONCLUSION}

After discussing HOTS model learning which is believed that is suitable for improving the quality of learning, both in schools and universities, the authors come to a conclusion: a) XXI Century learning must be able to provide skills to students, which includes: (1) critical thinking and problem solving, (2) creative and innovative, (3) collaboration, (4) communication; b) To be able to win the competition in the era of the industrial revolution 4.0, Indonesia's superior human resources must have the following skills: (1) languages (English, Mandarin, etc.), (2) logic (big data), (3) Ready to compete and to corporate; c) Indonesia needs superior human beings who have competitiveness and can answer challenges by providing solutions (problem finder and problem solver). The critical success factor, in essence, is in HR (Human Resources); d) Both government and private institutions are obliged to participate in the intellectual life of all the nation's children by advancing education and paying attention to the health sector; and e) By applying a HOTS-based learning model, it is hoped that it can answer problems in the field of education, including the placement of workers who have not linked and matched the world of education and the world of work as we feel today.

\section{SOURCES OF FUNDING}

This research received no specific grant from any funding agency in the public, commercial, or not-for-profit sectors.

\section{CONFLICT OF INTEREST}

The author have declared that no competing interests exist.

\section{ACKNOWLEDGMENT}

None.

\section{REFERENCES}

[1] Karakozov, S. D., \& Ryzhova, N. I. (2019). Information and education systems in the context of digitalization of education. Журнал Сибирского федерального университета. Серия: Гуманитарные науки, 12(9), 16351647.

[2] Mertala, P. (2020). Paradoxes of participation in the digitalization of education: A narrative account. Learning, Media and Technology, 45(2), 179-192.

[3] Dorofeeva, A. A., \& Nyurenberger, L. B. (2019, May). Trends in digitalization of education and training for industry 4.0 in the Russian Federation. In IOP Conference Series: Materials Science and Engineering (Vol. 537, No. 4, p. 042070). IOP Publishing.

[4] Pan, Y. (2016). Heading toward artificial intelligence 2.0. Engineering, 2(4), 409-413.

[5] Collins, G. S., \& Moons, K. G. (2019). Reporting of artificial intelligence prediction models. The Lancet, 393(10181), 1577-1579. 
[6] Guzey, S. S., \& Roehrig, G. H. (2009). Teaching science with technology: case studies of science teachers' development of technological pedagogical content knowledge (TPCK). Contemporary Issues in Technology and Teacher Education, 9(1), 25-45.

[7] Timms, M. J. (2016). Letting artificial intelligence in education out of the box: educational robots and smart classrooms. International Journal of Artificial Intelligence in Education, 26(2), 701-712.

[8] Canbek, N. G., \& Mutlu, M. E. (2016). On the track of artificial intelligence: Learning with intelligent personal assistants. Journal of Human Sciences, 13(1), 592-601.

[9] Tyas, E. H., \& Naibaho, L. (2020). Building Superior Human Resources through Character Education. TEST Engineering \& Management, 83, 11864-11873.

[10] Sormin, E., Julianti, K., Nadeak, B., \& Naibaho, L. (2019). Use of construction inquiry learning model to improve the interest of learning students grade XI SMA Angkasa 2 in colloid materials. PEOPLE International Journal of Social Sciences, 5(2), 908-917.

[11] Genlott, A. A., Grönlund, Å., \& Viberg, O. (2019). Disseminating digital innovation in school-leading secondorder educational change. Education and Information Technologies, 24(5), 3021-3039.

[12] Digeyasa, I. W., \& Naibaho, L. (2020). The Use of Google on Completing English Assignment by the Students of English Education Department At Universitas Negeri Medan. International Journal of Research, 8(6), 150-155.

[13] Sachs, J. D., Schmidt-Traub, G., Mazzucato, M., Messner, D., Nakicenovic, N., \& Rockström, J. (2019). Six transformations to achieve the sustainable development goals. Nature Sustainability, 2(9), 805-814.

[14] Chetty, K., Aneja, U., Mishra, V., Gcora, N., \& Josie, J. (2018). Bridging the digital divide in the G20: skills for the new age. Economics: The Open-Access, Open-Assessment E-Journal, 12(2018-24), 1-20.

[15] Naibaho, L. (2016). Phonological Acquisition of A Child Suffering from Language Delay. International Journal of Language Education and Culture Review, 2(1), 33-42.

[16] Naibaho, L. (2014). The Role of Education and Culture in the Development of Character and Civilization of the Plural Indonesian Nation. Jurnal the Ary Suta Center Series on Strategic Management, 27(0), 69.

[17] Tyas, E. H., \& Naibaho, L. (2020). Building a Culture of Tolerance since Early Childhood. International Journal of Research-GRANTHAALAYAH, 8(8), 244-249.

[18] Nadeak, B., \& Naibaho, L. (2019). Managing Lecturers' Competence Development at Universitas Kristen Indonesia.

[19] DeLeon, D. (2019). The American as anarchist: Reflections on indigenous radicalism. JHU Press.

[20] Nadeak, B., Juwita, C. P., Sormin, E., \& Naibaho, L. (2020). Hubungan kemampuan berpikir kritis mahasiswa dengan penggunaan media sosial terhadap capaian pembelajaran pada masa pandemi Covid-19. Jurnal Konseling dan Pendidikan, 8(2), 98-104.

[21] Nadeak, B., \& Naibaho, L. (2020). VIDEO-BASED LEARNING ON IMPROVING STUDENTS'LEARNING OUTPUT. PalArch's Journal of Archaeology of Egypt/Egyptology, 17(2), 44-54.

[22] McMahon, G. (2007). Getting the HOTS with what is in the box: Developing higher-order thinking skills within a technology-rich learning environment (Doctoral dissertation, Curtin University).

[23] Nadeak, B., \& Naibaho, L. (2020). Motivation and Hrm Factors Relation to the Employee Loyalty. Polish Journal of Management Studies, 22(2).

[24] Nadeak, B., \& Naibaho, L. (2020). The Effectiveness of Problem-Based Learning on Students'critical Thinking. Jurnal Dinamika Pendidikan, 13(1), 1-7.

[25] Situmorang, P. L., Maipita, I., \& Rahmadana, M. F. (2019). The Influence of Inquiry Learning Model and Achievement Motivation on HOTS Economic Learning Outcomes on 11th Grade Students. Budapest International Research and Critics Institute (BIRCI-Journal): Humanities and Social Sciences, 2(4), 609-615.

[26] Tyas, E. H., \& Naibaho, L. (2020). A harmony among of religious community is required amidst the covid-19 pandemic. International Journal of Research-GRANTHAALAYAH, 8(9), 422-428.

[27] Herbert, A. (2017). Didactics, Learning and Leadership in Higher Education: Understanding Strategy Development. Routledge.

[28] Liaw, S. S. (2008). Investigating students' perceived satisfaction, behavioral intention, and effectiveness of elearning: A case study of the Blackboard system. Computers \& Education, 51(2), 864-873.

[29] Sheridan, S. M., Edwards, C. P., Marvin, C. A., \& Knoche, L. L. (2009). Professional development in early childhood programs: Process issues and research needs. Early education and development, 20(3), 377-401.

[30] Gagne, R. M., Briggs, L. J., \& Wager, W. W. (1988). Instructional design. New York: Holt, Rinehart, Winston. 
[31] Bown, K., Sumsion, J., \& Press, F. (2009). Influences on Politicians' Decision Making for Early Childhood Education and Care Policy: what do we know? What don't we know?. Contemporary Issues in Early Childhood, 10(3), 194-217.

[32] Ali, A., \& Singh, C. K. S. (2020). ESBOR: Analysis Students HOTS for Develop Digital Technology in Environmental Learning.

[33] Singh, C. K. S., \& Marappan, P. (2020). A Review of Research on the Importance of Higher Order Thinking Skills (HOTS) In Teaching English Language. Journal of Critical Reviews, 7(8), 740-747.

[34] Türk, N., Kalayci, N., \& Yamak, H. (2018). New trends in higher education in the globalizing world: STEM in teacher education. Universal journal of educational research, 6(6), 1286-1304.

[35] National Research Council. (2000). Inquiry and the national science education standards: A guide for teaching and learning. National Academies Press.

[36] Cable, D. M., \& DeRue, D. S. (2002). The convergent and discriminant validity of subjective fit perceptions. Journal of applied psychology, 87(5), 875.

[37] Simanungkalit, I., Utanto, Y., \& RC, A. R. (2019). The Effectiveness of PBL-Based HOTS in English Learning. Innovative Journal of Curriculum and Educational Technology, 8(2), 67-73.

[38] Naibaho, L. (2019). Teachers'roles on English Language Teaching: A Students Centered Learning Approach. International Journal of Research-Granthaalayah, 7(4), 206-212. 